\title{
Effect of Feeding the Experimental Rats with Domiati Cheese on their Histopathological Alterations. \\ Ali, H. M. ${ }^{1}$; Deabes M. M. ${ }^{2}$; A. S. Soliman ${ }^{\mathrm{I}}$ and A. EL kholy ${ }^{1}$ \\ ${ }^{1}$ Department of Dairy, Faculty of Agriculture, Al Azhar University, Cairo, Egypt. \\ ${ }^{2}$ Food Toxicology and Contamination Department, National Research Center , Elgiza, Egypt.
}

\begin{abstract}
The aim of this work was to study the effect of feeding the experimental rats with Domiati cheese during storage on their histopathological alterations. To achieve this purpose, forty-two healthy rats were divided into three groups each of 12 rats. Each group fed daily one of the following diets for 120 days. Control rats fed on basal diet and water without any additives. Group (1) fed on control diet $+30 \%$ domiati cheese stored at room temperature, group (2) on control diet $+30 \%$ Domiati cheese stored in the refrigerator.At the end of the experiment; rats were sacrificed to obtain the livers, kidneys and examined for the histological examination. The microscopic examination of rats fed on Domiati cheese stored at room temperature and in the refrigerator showed histological changes in liver, kidney and testes tissues, compared to the control. These histological changes might be attributed to the high concentration of biogenic amines in the studied domiati cheese.
\end{abstract}

\section{INTRODUCTION}

Although the chemical composition and microbiological quality of Domiati cheese in the local markets have been studied extensively, little information, however, is available about the quality assurance systems being necessary during the steps during during the cheese industry to ensure its quality and safety. Storage temperatures can change the physiochemical properties of cheese. Among these changes the level of biogenic amines in cheese. For amines formation in cheese, low storage temperature provides unfavorable conditions (Wendakoon and Sakaguchi, 1993). Therefore, the present work was performed to examine the changes being occured to some constituents of domiati cheese during storage within the validity period, and thereafter, the effect of feeding of the experimental rats with stored domiati cheese on their histopathological alterations by investigating the relationship between the physiochemical properties of stored domiati cheese and the histological characteristics of the experimental rats.

\section{MATERIALS AND METHODS}

Fresh whole buffalo's milk was obtained from the herd of Faculty of Agriculture, Al- Azhar University, Mostorod, Cairo, Egypt. Rennet powder, of CHR Hansen's Laboratory, Copenhagen, Denmark was used. Commercial sodium chloride was obtained from ElNasr Company (Alexandria Egypt). Fine calcium chloride good grad " $\mathrm{CaCl}_{2}$ " was obtained from Caso Company, Italy. It was imported by El-Zawawi Company, El-Gesh Street, Cairo, Egypt.

Chloroform, n-butanol, n-heptane, acetone, sodium hydroxide, sodium bicarbonate, hydrochloric acid and trichloroacetic acid (T.C.A) were produced by (Adwic- Co., El nasr pharmaceutical chemicals, A.R.E.). Methanol, acetonitrile, diethylether and acetic acid of HPLC grade, produced by (BDH, England) were used. The pure standard biogenic amines and dansyl chloride were produced by (Sigma- Co., Louis, MO 63178 U.S.A).

The experimental animals used in the present work were forty-two healthy male albino rats weighting (80-100g) were purchased from the Biological Products and Vaccines Holding Company, Helwan Farm. Cairo. Egyptian standard synthetic diet, which constituted of
$12 \%$ casein, $8 \%$ corn oil, $4 \%$ salt mixture, $1 \%$ vitamins mixture, $5 \%$ fiber (bran) and $70 \%$ starch as described by Ismail, (2013) was used.

Domiati cheese making was followed due to the traditional method being described by Fahmi and Sharara, (1950). Moisture content was determined according to B.S.I., (1955). Titratable acidity, fat, and salt contents were determined according to the methods reported by ling, (1963). $\mathrm{pH}$ values of cheese samples were measured using a laboratory digital $\mathrm{pH}$ meter model Adwa 1030. Ash content was measured according to A.O.A.C. (2012). Thiobarbituric acid (TBA) was detected by the method described by Pearson, (1981).

For the determination of Biogenic amines, six biogenic amines included histamine, tyramine, putrescine, cadaverine, spermine and spermidine were extracted and determined according to Mietz and Karmas, (1977).

Total bacterial and coliform counts were determined according to APHA, (1992).

For Housing of experimental animals, Rats were housed in stainless steel cages under ambient temperature conditions (at $20 \pm 5^{\circ} \mathrm{C}$ and $65 \pm 5$ ) and relative humidity), and allowed to acclimatize for a period of 15 days prior to experimental use. All animals were healthy and clinically free from diseases. Forty-two rats were randomly divided into 3 equal groups, each of 14 individuals, and fed daily on one of the following diets for 120 days:

Control: Rats fed on Control diet (Basal Diet and water without any additives).

Group (1): Rats fed on Control diet $+30 \%$ Domiati cheese was storage at room temperature.

Group (2): Rats fed on Control diet $+30 \%$ Domiati cheese was storage at Refrigerator temperature.

As with the histopathological examination, rats were sacrificed at the end of the experiment to obtain the livers, kidneys and testes. Immediately after extraction, the livers, kidneys and testes were immersed in formalin concentration $10 \%$ until the histopathological examination. Liver, kidneys, and testes tissues were dissected out and fixed instantaneously in $10 \%$ formal saline for 24 hours. The specimens were washed with tap water, dehydrated in ascending grades of ethanol, cleared in xylene, embedded in paraffin wax (melting point $55-60^{\circ} \mathrm{C}$ ). Sections of $6 \mu \mathrm{m}$ thickness were prepared and stained with Hematoxylin and eosin (Drury and Wallington, 
1980). In this method, the paraffin sections were stained in Harris's hematoxylin for 5 minutes. Sections were washed in running water for bluing and then stained in $1 \%$ watery eosin for 2 minutes, washed in water, dehydrated, cleared and mounted in Canada balsam.

The cytoplasm stained in shades of pink to red and the nuclei gave blue colour. Observations were made using a light microscope (Zeiss Axiophot, Germany) and photographs were taken with an automatic photomicrographic system.

Finally, all of the obtained data were subjected to statistical analysis of variance, and treatment means were compared by Duncan's test at the $5 \%$ level of probability according to (Gomez and Gomez, 1984).

\section{RESULTS AND DISCUSSION}

Physiochemical properties changes of domiati cheese during storage.

Table 1. Physiochemical properties of Domiati cheese during storage.

\begin{tabular}{|c|c|c|c|c|c|c|}
\hline $\begin{array}{c}\begin{array}{c}\text { Storage } \\
\text { temperature }\end{array} \\
\end{array}$ & \multirow[t]{2}{*}{ Properties } & \multicolumn{5}{|c|}{ Storage periods (days) } \\
\hline \multirow{9}{*}{$\begin{array}{l}\text { Room } \\
\text { temperature }\end{array}$} & & Fresh & 30 & 60 & 90 & 120 \\
\hline & Moisture $\%$ & $61.96^{\mathrm{D}} \pm 0.12$ & $59.76^{\mathrm{G}} \pm 0.28$ & $57.84^{1} \pm 0.19$ & $55.76^{\mathrm{K}} \pm 0.48$ & $52.55^{\mathrm{N}} \pm 0.63$ \\
\hline & $\mathrm{PH} v$ & $6.41^{\mathrm{A}} \pm 0.026$ & $5.37^{\mathrm{F}} \pm .036$ & $4.70^{\mathrm{G}_{ \pm}} .056$ & $4.35^{\mathrm{K}_{ \pm}} .056$ & $3.96^{\mathrm{O}} \pm .082$ \\
\hline & Titratable & $0.18^{S_{ \pm}} .006$ & $0.57^{\mathrm{P}} \pm .015$ & $0.79^{\mathrm{M}_{ \pm} .040}$ & $1.13^{\mathrm{GH}_{ \pm 0}} 0.035$ & $1.44^{\mathrm{C}} \pm .050$ \\
\hline & $\mathrm{S}$ & $5.59^{\mathrm{C}} \pm .025$ & $5.21^{\mathrm{E}} \pm .035$ & $5.01^{\mathrm{F}} \pm .035$ & $4.89^{\mathrm{G}} \pm .035$ & $4.72^{\mathrm{H}} \pm .036$ \\
\hline & & $5.97^{\mathrm{F}} \pm .055$ & $6.15^{\mathrm{E}} \pm .045$ & $6.44^{\mathrm{D}} \pm .114$ & $6.75^{\mathrm{C}} \pm .080$ & $6.96^{\mathrm{B}} \pm .070$ \\
\hline & & $13.03^{\mathrm{N}} \pm 0.764$ & $15.17^{\mathrm{M}_{ \pm}} 0.289$ & $15.83^{\mathrm{L}} \pm 0.577$ & $17.00^{\mathrm{K}} \pm 0.500$ & $18.67^{\mathrm{J}} \pm 0.289$ \\
\hline & Thiobarbituric & $0.07^{\mathrm{M}_{ \pm} .008}$ & $0.10^{\mathrm{JKLM}_{ \pm}} 0.021$ & $10.13^{\mathrm{IJKLM}_{ \pm}}+0.023$ & $30.20^{\mathrm{EFGH}_{ \pm}} 0.028$ & $0.27^{\mathrm{D}} \pm .016$ \\
\hline & Total $\mathrm{p}$ & $13.2^{\mathrm{E}} \pm .040$ & $14.22^{\mathrm{BC}} \pm 0.040$ & $14.5^{\mathrm{A}} \pm .025$ & $14.7^{\mathrm{B}} \pm .040$ & $14.9^{\mathrm{CD}_{ \pm}} 0.025$ \\
\hline \multirow{8}{*}{$\begin{array}{l}\text { Refrigerator } \\
\text { temperature }\end{array}$} & Moisture \% & $61.96^{\mathrm{D}} \pm 0.12$ & $63.01^{\mathrm{A}} \pm 0.07$ & $62.13^{\mathrm{CD}} \pm 0.14$ & $60.82^{\mathrm{F}} \pm 0.36$ & $58.82^{\mathrm{H}} \pm 0.31$ \\
\hline & $\mathrm{PH}$ value & $6.41^{\mathrm{A}} \pm 0.026$ & $6.03^{\mathrm{B}} \pm .044$ & $5.83^{\mathrm{C}} \pm .036$ & $5.72^{\mathrm{D}} \pm 0.036$ & $5.49^{\mathrm{E}} \pm .010$ \\
\hline & Titratable acidity $\%$ & $0.18^{\mathrm{S}} \pm .006$ & $0.25^{\mathrm{R}} \pm .020$ & $0.44^{\mathrm{Q}_{ \pm}} .021$ & $0.53^{\mathrm{P}} \pm .040$ & $0.71^{\mathrm{O}_{ \pm}} \pm .025$ \\
\hline & Salt content $\%$ & $5.59^{C} \pm 0.025$ & $5.86^{\mathrm{A}} \pm 0.036$ & $5.66^{\mathrm{B}} \pm 0.026$ & $5.51^{\mathrm{D}_{ \pm}} 0.021$ & $5.23^{\mathrm{E}} \pm 0.040$ \\
\hline & Ash content $\%$ & $5.97^{\mathrm{F}} \pm 0.055$ & $6.21^{\mathrm{E}} \pm 0.060$ & $6.46^{\mathrm{D}} \pm 0.074$ & $6.90^{\mathrm{B}} \pm 0.070$ & $7.25^{\mathrm{A}} \pm 0.106$ \\
\hline & Fat content $\%$ & $13.03^{\mathrm{N}} \pm 0.764$ & $13.00^{\mathrm{O}} \pm 0.000$ & $13.33^{\mathrm{NO}_{ \pm}} 0.289$ & $13.67^{\mathrm{NO}_{ \pm}} 0.289$ & $14.83^{\mathrm{M}_{ \pm}} 0.289$ \\
\hline & Thiobarbituric acid (TBA) test & $0.07^{\mathrm{M}_{ \pm}} 0.008$ & $0.09^{\mathrm{KLM}_{ \pm}} \pm 0.021$ & $0.11^{\mathrm{JKLM}_{ \pm}} \pm .016$ & $0.18^{\mathrm{FGHI}} \pm 0.021$ & $0.22^{\mathrm{DEF}} \pm 0.021$ \\
\hline & Total protein $\%$ & $13.2^{\mathrm{E}} \pm 0.040$ & $13.4^{\mathrm{G}} \pm 0.020$ & $13.7^{\mathrm{F}} \pm 0.020$ & $13.8^{\mathrm{DE}} \pm 0.040$ & $13.88^{\mathrm{CD}} \pm 0.025$ \\
\hline
\end{tabular}

Changes in the biogenic amines levels of domiati cheese during storage:

Biogenic amines formation affected with some factors, for example $\mathrm{pH}$, salt concentration, bacterial activity, moisture, storage temperature and maturation time of the examined cheese was detected. An important factor for the formation of biogenic amines in cheese is the presence of microorganisms with decarboxylase activity (Linares et al., 2011). The consumption of food containing high amounts of histamine and other biogenic amines can result in food poisoning with different symptoms due to the sensitivity of the individual and the activity of detoxification.

The obtained data in Table (2) show that the total biogenic amines levels in domiati cheese increased during the storage period. The increase in the levels of biogenic amines stored at room temperature were significantly higher than that in the cheese stored in refrigerator. Levels of amines in the cheese stored at room temperature were higher than the permissible limits ( $90 \mathrm{mg} / 100 \mathrm{~g}$ food), where the concentrations of amines above $(90 \mathrm{mg} / 100 \mathrm{~g})$ have a serious negative impact on the consumer health. These limits were
Results in Tale (1) show that the analysis of variance of moisture, $\mathrm{pH}$ values and salt contents of Domiati cheese decreased significantly $(\mathrm{P} \leq 0.05)$ at room and refrigerated temperature during storage period. This decrease could be attributed to the contraction of curd as a result of the development of acidity resulting from the converstion of residual lactose into lactic acid by microflora during storage. The contraction of curd helps to expel the whey out of the curd. Similar results were reported by Gamal El- Din et al., 2012 and Hamad, (2015). On the other hand, the statistical analysis indicated that fat, ash, titratable acidity, thiobarbituric acid and total protein contents of domiati cheese increased significantly $(\mathrm{P} \leq 0.05)$ by storing at room and refrigerator temperature, with the progress of the period. This increase could be attributed to the decrease in moisture content. The present results are in agreement with Abdalla, 2007). confirmed by Standarová et al., (2010) and Shalaby (1996).

Microbiological changes of Domiati cheese during storage:

The obtained data in Table (3) demonstrated that the total viable bacterial count of Domiati cheese stored at room temperature increased until the end of the first month, followed by decrease till the end of the storage period. While total viable bacterial count of Domiati cheese stored at refrigeration temperature increased until the end of the second month, followed by decrease till the end of the storage period. This decrease would evidently be attributed to the increase in titratable acidity of Domiati cheese, which reduces the rate of bacterial growth. Similar trends were observed by Aly and Galal, (2002), ;Aly, (2002) and El-Alfy et al., (2004). It could also be observed that the coliform group was absent during storage period, which might be attributed to the efficient heat treatment being used on the cheesemilk, the sanitary conditions during the cheese making and the length of the storage period. These results are in agreement with those given by Kebary et al.,(2015). 
Table 2. Biogenic amines levels (mg / 100g) of Domiati cheese during storage.

\begin{tabular}{|c|c|c|c|c|c|c|}
\hline \multirow{2}{*}{\begin{tabular}{l}
\multicolumn{1}{c}{$\begin{array}{c}\text { Storage } \\
\text { temperature }\end{array}$} \\
Room \\
temperature
\end{tabular}} & \multirow{2}{*}{ Properties } & \multicolumn{5}{|c|}{ Storage periods (days) } \\
\hline & & Fresh & 30 & 60 & 90 & 120 \\
\hline & Histamine levels & $0.29^{\mathrm{Y}} \pm 0.295$ & $2.39^{\mathrm{V}} \pm 0.115$ & $5.05^{\mathrm{R}} \pm 0.071$ & $12.83^{\mathrm{G}} \pm 0.075$ & $18.68^{C} \pm 0.056$ \\
\hline & Tyramine levels & $1.53^{\mathrm{Y}} \pm 0.132$ & $2.78^{\mathrm{W}} \pm 0.110$ & $9.45^{\mathrm{R}} \pm 0.066$ & $12.87^{\mathrm{M}_{ \pm}} 0.067$ & $17.38^{\mathrm{J}} \pm 0.065$ \\
\hline & Putrescine levels & $1.12^{\mathrm{T}} \pm 0.065$ & $8.82^{\mathrm{OP}} \pm 0.061$ & $14.67^{\mathrm{K}} \pm 0.125$ & $18.57^{\mathrm{F}} \pm 1.776$ & $26.23^{C_{ \pm}} 0.040$ \\
\hline & Cadaverine levels & $1.40^{\mathrm{Y}} \pm 0.046$ & $6.68^{\mathrm{V}} \pm 0.105$ & $18.91^{\mathrm{I}} \pm 0.038$ & $22.41^{\mathrm{G}} \pm 0.056$ & $35.01^{\mathrm{C}} \pm 0.086$ \\
\hline & Spermidine levels & $0.00{ }^{S} \pm 0.000$ & $0.67^{\mathrm{Q}} \pm 0.046$ & $3.27^{\mathrm{I}} \pm 0.065$ & $4.87^{\mathrm{H}_{ \pm}} \pm 0.080$ & $6.35^{\mathrm{E}} \pm 0.060$ \\
\hline & Spermine levels & $2.86^{\mathrm{Y}} \pm 0.098$ & $5.68^{\mathrm{U}} \pm 0.095$ & $9.17^{\mathrm{Q}} \pm 0.075$ & $14.58^{\mathrm{I}} \pm 0.090$ & $19.15^{\mathrm{E}} \pm 0.045$ \\
\hline & $\begin{array}{l}\text { Total biogenic } \\
\text { amines }\end{array}$ & 7.20 & 27.02 & 60.52 & 86.13 & 122.80 \\
\hline \multirow{7}{*}{$\begin{array}{l}\text { Refrigerator } \\
\text { temperature }\end{array}$} & Histamine levels & $0.29^{\mathrm{Y}} \pm 0.295$ & $1.03^{\mathrm{X}} \pm 0.046$ & $2.22^{\mathrm{W}} \pm 0.070$ & $4.76^{\mathrm{S}} \pm 0.055$ & $6.18^{\mathrm{Q}} \pm 0.044$ \\
\hline & Tyramine levels & $1.53^{\mathrm{Y}} \pm 0.132$ & $1.60^{\mathrm{Y}} \pm 0.031$ & $2.15^{\mathrm{x}} \pm 0.055$ & $6.08^{\mathrm{V}} \pm 0.047$ & $9.55^{\mathrm{R}} \pm 0.074$ \\
\hline & Putrescine levels & $1.12^{\mathrm{T}} \pm 0.065$ & $1.58^{\mathrm{T}} \pm 0.066$ & $2.41^{\mathrm{S}_{ \pm}}+0.035$ & $5.26^{\mathrm{R}} \pm 0.032$ & $8.53^{P} \pm 0.040$ \\
\hline & Cadaverine levels & $1.40^{\mathrm{Y}} \pm 0.046$ & $2.97^{\mathrm{x}} \pm 0.075$ & $4.62^{\mathrm{w}} \pm 0.042$ & $7.32^{\mathrm{U}} \pm 0.031$ & $12.22^{\mathrm{O}} \pm 0.045$ \\
\hline & Spermidine levels & $0.00 \mathrm{~S}_{ \pm 0.000}$ & $0.40^{\mathrm{R}} \quad \pm 0.025$ & $1.21^{\mathrm{P}} \pm 0.055$ & $1.98^{\mathrm{N}} \pm 0.010$ & $2.93^{K_{ \pm}}+0.055$ \\
\hline & Spermine levels & $2.86^{\mathrm{Y}} \pm 0.098$ & $3.05^{\mathrm{X}} \pm 0.050$ & $4.42^{\mathrm{W}} \pm 0.060$ & $7.82^{\mathrm{S}} \pm 0.040$ & $10.11^{\mathrm{O}} \pm 0.045$ \\
\hline & $\begin{array}{c}\text { Total biogenic } \\
\text { amines }\end{array}$ & 7.20 & 10.62 & 17.03 & 33.20 & 49.51 \\
\hline
\end{tabular}

Table 3. Microbiological properties of domiati cheese during storage.

\begin{tabular}{|c|c|c|c|c|c|c|}
\hline $\begin{array}{l}\text { Storage } \\
\text { temperature }\end{array}$ & Microbial type & \multicolumn{5}{|c|}{ Storage periods (days) } \\
\hline Room & & Fresh & 30 & 60 & 90 & 120 \\
\hline temperature & $\begin{array}{l}\text { Total viable bacterial count }(\mathrm{CFU} / \mathrm{g}) \\
\text { coliform bacterial count }(\mathrm{CFU} / \mathrm{g})\end{array}$ & $\begin{array}{l}37 \times 10^{5} \\
\mathrm{ND}\end{array}$ & $\begin{array}{l}70 \times 10^{5} \\
\mathrm{ND}\end{array}$ & $\begin{array}{l}41 \times 10^{5} \\
\mathrm{ND}\end{array}$ & $\begin{array}{l}12 \times 10^{5} \\
\mathrm{ND}\end{array}$ & $\begin{array}{l}0.4 \times 10^{5} \\
\mathrm{ND}\end{array}$ \\
\hline $\begin{array}{l}\text { Refrigerator } \\
\text { temperature }\end{array}$ & $\begin{array}{l}\text { Total viable bacterial count }(\mathrm{CFU} / \mathrm{g}) \\
\text { coliform bacterial count }(\mathrm{CFU} / \mathrm{g})\end{array}$ & $\begin{array}{l}37 \times 10^{5} \\
\mathrm{ND}\end{array}$ & $\begin{array}{l}47 \times 10^{5} \\
\mathrm{ND}\end{array}$ & $\begin{array}{c}49 \times 10^{5} \\
\text { ND }\end{array}$ & $\begin{array}{l}37 \times 10^{5} \\
\mathrm{ND}\end{array}$ & $\begin{array}{l}3.6 \times 10^{5} \\
\text { ND }\end{array}$ \\
\hline
\end{tabular}

ND $=$ Not found

Effect of feeding with domiati cheese on liver hithtopathological alterations of the experimental rats.

The microscopic examination of control rats' liver that fed on basal diet and water without Domiati cheese showed normal structure of the hepatic lobules (Figure1) . Histopathological investigation of rats liver that fed on Domiati cheese stored at room temperature showed macroand micro- vacuoles in the hepatocytes cytoplasm (Fig.2). In some rats, examination of liver showed congested portal area associated with inflammation and infiltration (Fig. 3).

Micrograph of liver in rats that fed on Domiati cheese stored at refrigeration temperature showed a vacuolation in the hepatocytes cytoplasm (Fig.4).On the other hand ,the liver of other rats showed normal structure of the hepatic lobules (Fig.5). The histological changes that occurred in the rats' liver might be due to an increase in the biogenic amines levels of Domiati cheese. These results are in agreement with El-Zahar et al., (2014).

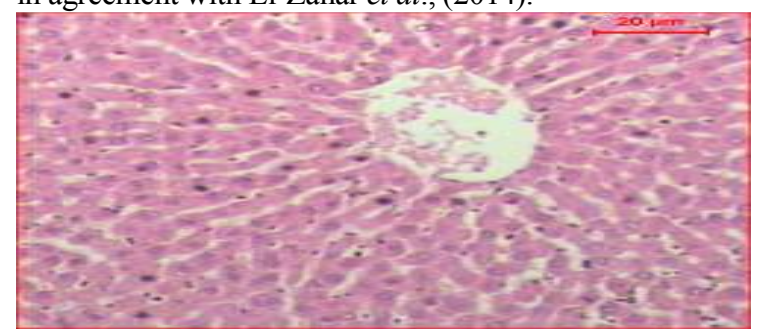

Figure1.Liver micrograph of control rats that fed on basal diet and water without Domiati cheese showed normal structure of the hepatic lobules.

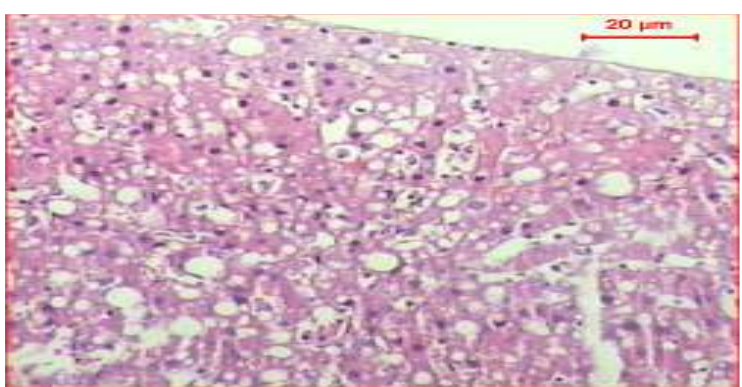

Figure 2. liver micrograph of rats that fed on Domiati cheese was stored at room temperature showed macro and micro vacuoles in the hepatocytes cytoplasm .

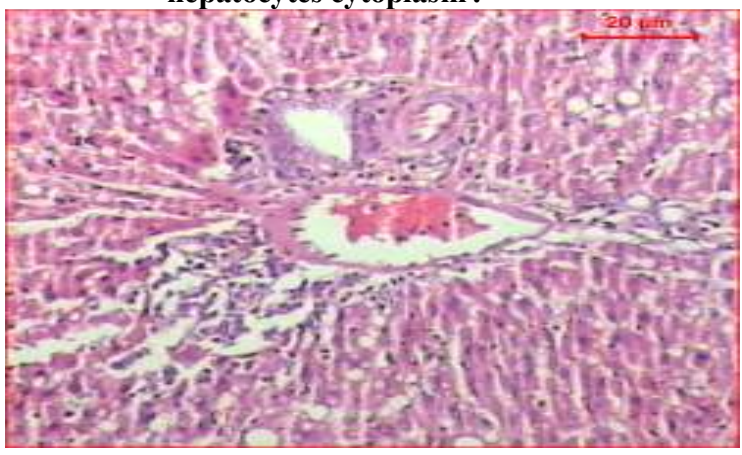

Figure 3. liver micrograph of rats that fed on Domiati cheese was stored at room temperature showed congested portal area associated with inflammation and infiltration. 


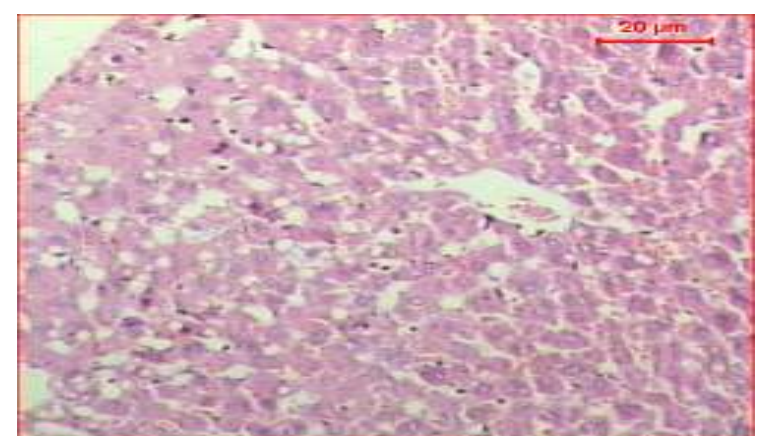

Figure 4. liver micrograph of rats that fed on Domiati cheese was stored at refrigerator temperature show a vacuolation in the hepatocytes cytoplasm .

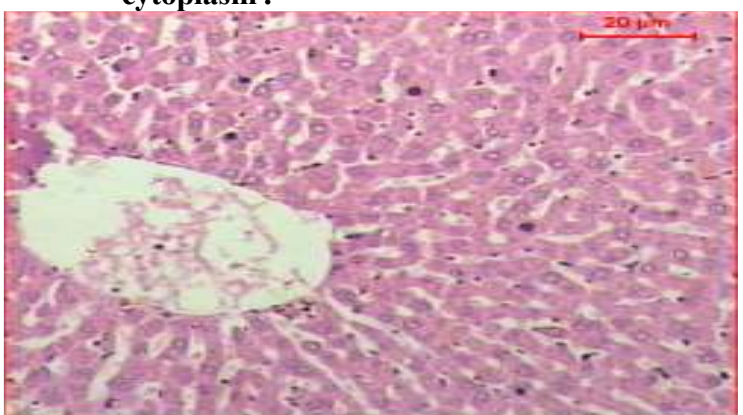

Figure 5. liver micrograph of rats that fed on Domiati cheese was stored at refrigerator temperature showed normal structure of the hepatic lobules

Effect of feeding with Domiati cheese on kidney histopathological alterations of the experimental rats.

As shown in Figure (6), kidney micrograph of rats that fed on basal diet and water without any additives showed normal structure of the renal corpuscles and tubules. The microscopic examination of rats' kidney that fed on Domiati cheese being stored at room temperature showed large foci of hemorrhage in the tubules interstitial areas and degenerative renal tubules. Thickened blood vessel and fibrotic area are observed (Figure 7). Kidney micrograph of rats that fed on Domiati cheese which was stored at refrigeration temperature shows areas of hemorrhage and edema in the tubules interstitial areas(Figure 8).Also, kidney micrograph of rats that fed on Domiati cheese being stored at refrigeration temperature showed degenerative renal tubules, and partially degenerative renal corpuscles(Figure 9). The observed histopathological changes of the kidney in the present work are in agreement with those obtained by El-Zahar et al., (2014).

Effect of feeding with Domiati cheese on testis hithtopathological alterations of the experimental rats.

The histological observations showed that the testes of control rats had normal arrangement of seminiferous tubules with spermatogenic cells. Evidence of apparently intact seminiferous tubules, as well as active cell division and maturation of the germ cells as evidenced in terminally differentiated cells/spermatozoa, are shown (Fig. 10). Examination of testes micrograph in rats that fed on Domiati cheese stored at room temperature showed atrophy of the tissues and disturbance in spermatogenic cell layers (Fig11). While testes of rats that fed on Domiati cheese stored at refrigeration temperature showed that the seminiferous tubules appeared more or less like control and associated with normal epithelia (Fig.12).

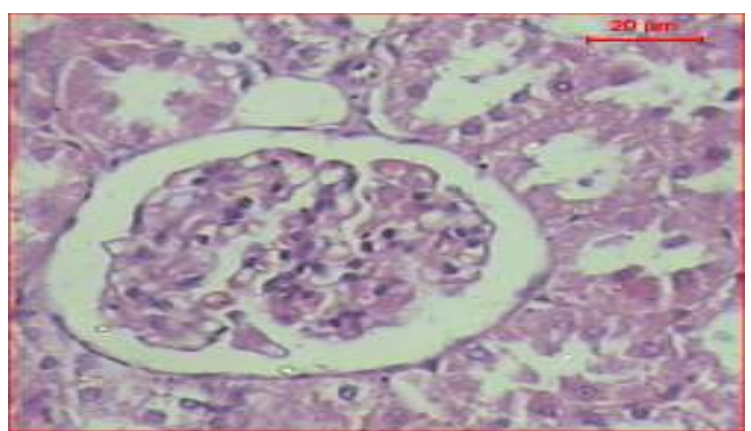

Figure 6. kidney micrograph of rats that fed on basal diet and water without any additives showed normal structure of the renal corpuscles and tubules.

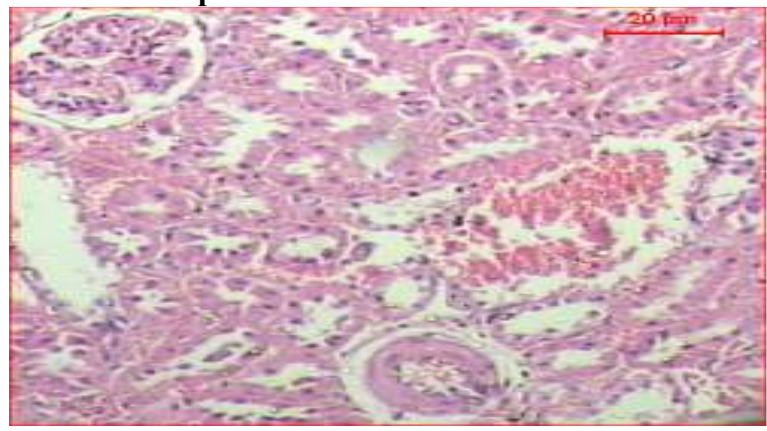

Figure 7. kidney micrograph of rats that fed on Domiati cheese was stored at room temperature showed large foci of hemorrhage in the tubules interstitial areas and degenerative renal tubules. Thickened blood vessel and fibrotic area are seen .

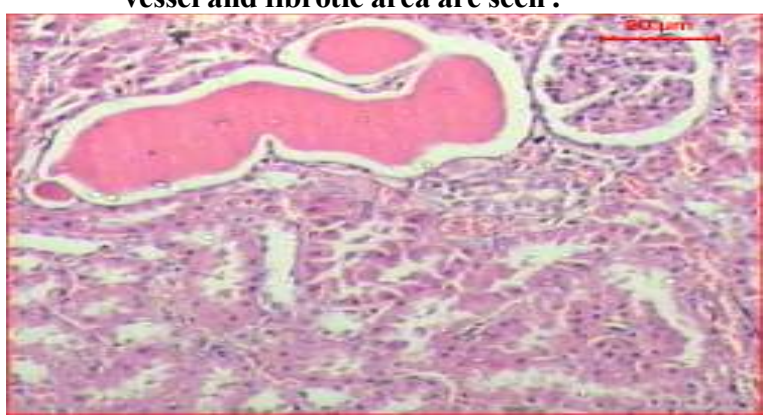

Figure 8. kidney micrograph of rats that fed on Domiati cheese was stored at refrigerator temperature shows areas of hemorrhage and edema in the tubules interstitial areas 


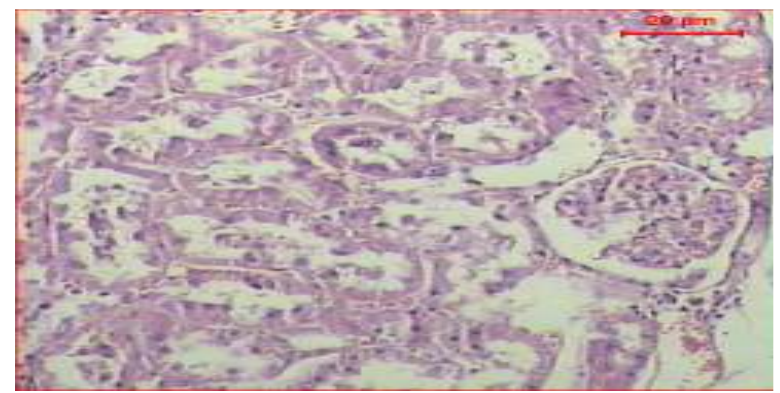

Figure 9. kidney micrograph of rats that fed on Domiati cheese was stored at refrigerator temperature shows degenerative renal tubules and partially degenerative renal corpuscles.

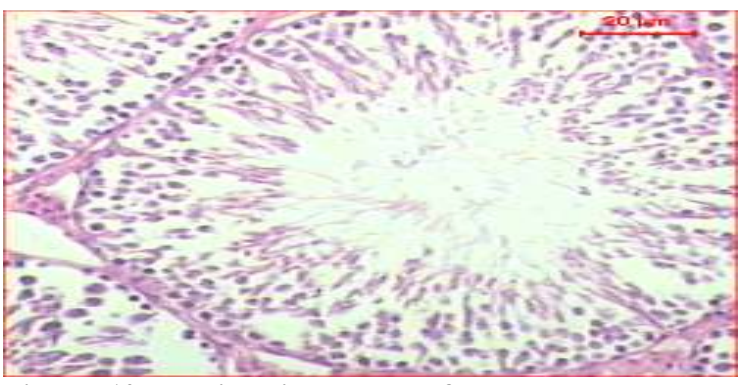

Figure 10. Testis micrograph of control rats showed normal structure of seminiferous tubules containing different types of spermatogenic cells.

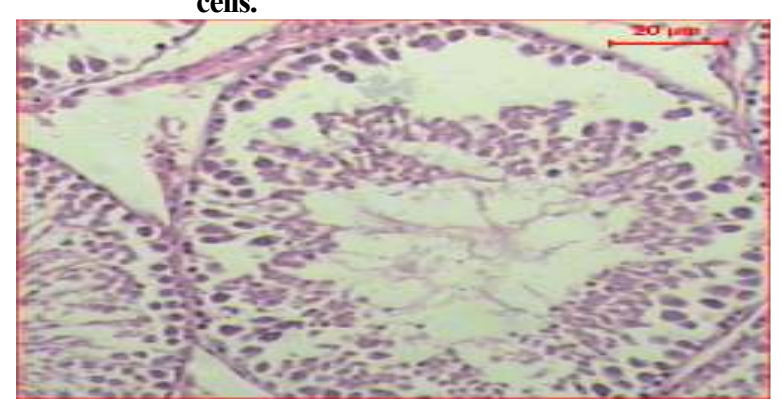

Figure 11. Testis micrograph of rats that fed on Domiati cheese was stored at room temperature showed atrophy of the tissue and disturbance in spermatogenic cell layers.

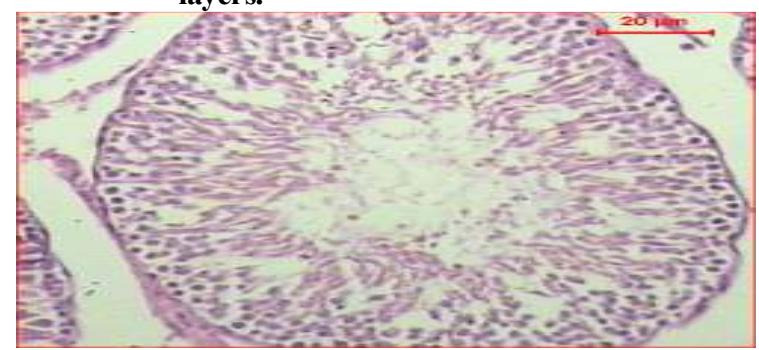

Figure 12. Testis micrograph of rats that fed on Domiati cheese was stored at refrigerator temperature shows the seminiferous tubules revealed that its structure are more or less like control and associated with normal epithelia .

\section{REFERENCES}

A.O.A.C, (2012). Association of official analytical chemists, $19^{\text {th }}$, official methods of chemical analysis, maryland, USA.

Abdalla, M. I. (2007). Effect of packaging material on the storage quality of Sudanese soft cheese. Ph.D. Thesis, Department of Food Science and Technology, Faculty of Agriculture, University of Khartoum, Sudan.

Ali, S. A. and Galal, E.A. (2002). Effect of milk pretreatment on the keeping quality of Domiati cheese. Pakistan Journal of Nutrition 1 (3): 132136.

American Public Health Association (1992). Compendium of methods for the microbiological examination of foods. 3TH. ED. (APHA). Washington, DC.

British Standard Institution (BSI) Methods (1950). Publ No.696, part 2.

Drury, R. A. B. and Wallington, E. A. (1980). Carleton's histological technique- $4^{\text {th }} \mathrm{Ed}$ - oxford. Oxford University press.

El-Alfy, M. B.; Younis, M. F.; Abd El-Aty, A. M.; Osman, SH. G. and Gafour, W.A. (2004). The implication of using soybean milk and probiotic for Feta-like cheese making. Annals of Agric. Sci., Moshtohor, 42(4):1727-1742.

El-Zahar, K. M. (2014). Biogenic Amines and Microbiological Profile of Egyptian Cheeses. Universal Journal of Food and Nutrition Science, 2(1), 18-26.

Fahmi, A. H. and Sharara, H. A. (1950). Studies on Egyptian Domiati cheese. J. Dairy Res. 17(3), 312-328.

Gamal El-Din, A. M.; Hassan, A. S. H.; El-Behairy, S. A. and Mohamed, E. A. (2012). Impact of zinc and iron salts fortification of buffalo's milk on the dairy product. World Journal of Dairy and Food Sciences, 7(1), 21-27.

Gomez, K. N. and Gomez, A. A. (1984) Statistical procedures for agricultural research. John Wiley and Sons, New York $2^{\text {nd }}$. Ed68p.

Hamad, M. N. F. (2015). Comparative study between traditional Domiati cheese and recombined Feta cheese. Indian J. Dairy Sci, 68 (5), 442-452.

Ismail,E.L.A(2013).Tecnological and nutritional studies on some supplemented bakery products prepared for school students consumption.M.Sc.; Thesis, Fac.Gric.;AL-Azhar Univ.;Egypt.

Kebary, K. K.; El-Shazly, H. A. and Youssef, I. T. (2015). Quality of Probiotic UF Domiati

Cheese made by Lactobacillus rhamnosus. International Journal of Current Microbiology

Applied Science, 4(7), 647 - 656

Linares, D. M.; Martín, M.; Ladero, V.; Alvarez, M. A. and Fernández, M. (2011). Biogenic amines in dairy products. Critical reviews in food science and nutrition, 51(7), 691-703. 


\section{Ali, H. M. et al.}

Ling, E. R. (1963). A Text book of Dairy Chemistry. Vol. 2,3 ed. Chapman and Hall, Ltd., London.

Mietz, J. L. S. and Karmas, E. (1977). Chemical Quality index of canned tuna as determined by high pressure liquid chromatography. J. Food Sci. 42, 155-158.

Pearson, D.; Egan, H.; Kirk, R. S. and Sawyer, R. (1981). Pearson's Chemical Analysis of Foods. 8th Edn., Longman Scientific and Technical, New York, USA., pp: 536-538.

Shalaby, A. R. (1996). Significance of biogenic amines to food safety and human health. Food Research International, 29(7), 675 - 690 .
Standarová, E.; Vorlová, L.; Kordiovská, P.; Janštová, B.; Dračková, M. and Borkovcová, I. (2010). Biogenic amine production in Olomouc curd cheese (Olomoucké tvarůžky) at various storage conditions. Acta Veterinaria Brno, 79 (1), 147156.

Wendakoon, C. N. and Sakaguchi, M. (1993). Combined effects of sodium chloride and clove on growth and biogenic amine formation of Enterobacter aerogenes in mackerel muscle extract. Journal of food protection. 56 (5), 410413.

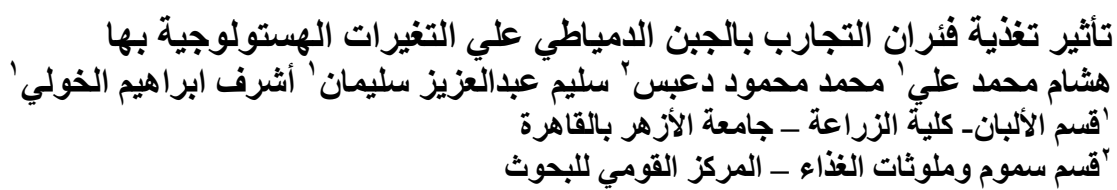

تم في هذا البحث دراسة تأثير تغذية فئران التجارب علي الجبن الدمياطي خلال التخزين علي التغيرات الهستولوجية

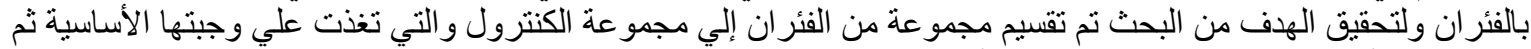

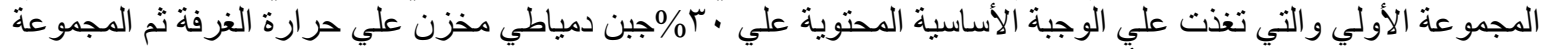

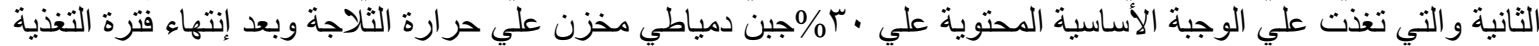

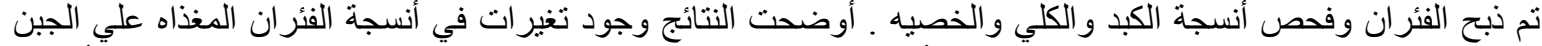

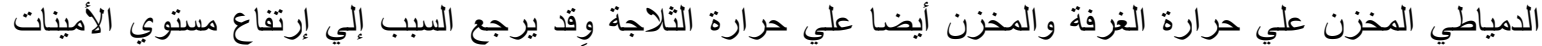

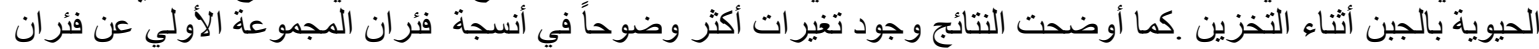

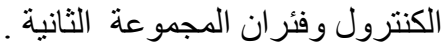

